\title{
Factors Affecting Collaboration Portal Effectiveness of the Audit Board of Indonesia
}

\author{
Afrialdi Syahputra ${ }^{1}$, Paulus Insap Santosa ${ }^{2}$, Rudy Hartanto ${ }^{3}$
}

\begin{abstract}
The Audit Board of the Republic of Indonesia is known as Badan Pemeriksa Keuangan (BPK). In carrying out its duties and functions, it empowers and relies on information technology (IT) infrastructure that covers all aspects, including planning, procurement, service provision, information asset security, service continuity, and evaluation. BPK implements a collaboration portal to meet service needs and teamwork during the audit process, ad-hoc committees, and leader instructions to follow BPK's strategic plan. BPK needs to assess the effect of the collaboration portal in supporting employee performance and improving IT services. As a result, this study aims to investigate the factors that influence the effectiveness of the BPK collaboration portal. This study used Delone and McLean model of information system success by looking at the relationship of system quality, information quality, service quality, facilitating conditions, and collaboration quality to user satisfaction and individual job performance. The research method used a quantitative approach with partial least squares-structural equation modeling (PLS-SEM). The sample data was collected from 60 respondents at $B P K$. The data obtained from the respondents were processed using the SmartPLS application. The study results show that information quality, facilitating conditions, and collaboration quality positively and significantly affect user satisfaction. There is a positive and significant influence of user satisfaction on individual job performance. In addition, system quality and service quality do not significantly influence user satisfaction with collaboration portal services.
\end{abstract}

Keywords-Collaboration Portal, BPK, Effectiveness, DeLone and McLean.

\section{INTRODUCTION}

Badan Pemeriksa Keuangan (BPK) empowers and relies on information and communication technology (ICT) infrastructure in carrying out its duties and functions, covering all aspects ranging from planning, procurement, service provision, information asset security, service continuity, and evaluation. BPK implements a collaboration portal which expected to meet the need for services and improve teamwork during the audit process, ad-hoc committees, and carry out leader's instructions.

Based on [1], a collaboration portal can be called an enterprise portal. The term corporate portal is often used together with the terms corporate information portal, enterprise information portal, and business portal. A corporate portal usually provides specific information according to the organization's needs to help users find information more easily.

1,2,3 Department of Electrical and Information Engineering, Faculty of Engineering, Universitas Gadjah Mada, Jln. Grafika 2, Kampus UGM Yogyakarta, 55281, INDONESIA (phone: 0274552305; email:_lafrialdi.syahputra@mail.ugm.ac.id, 2insap@ugm.ac.id, ${ }^{3}$ rudy@ugm.ac.id)
In addition, it is an evolution of the intranet that allows organizations to identify, view, record, store, track, and distribute large amounts of valuable information to employees and teams from various internal and external sources. The primary function of a corporate portal is for decision-making and collaboration processes [2]. Meanwhile, collaboration is defined as a joint action or coordination between individuals supported by communication to find one another easily, exchange messages synchronous and asynchronously, share applications, documents, workflows, and others [3].

The development of a sustainable portal takes time to match the needs of BPK. The presence of a portal can have negative impact if stakeholders do not identify essential factors for the benefit of the long-term use [4]. The underlying reason for portal failure is the organization's inability to understand the positive aspects of using the portal [5] and not consider the impact of intangibles and environmental variables [6]. In addition, the development and implementation of portals tend to be different from the development of information systems in general in terms of scale, scope, organizational change, complexity, and cost, so that portal implementation becomes more complex, requires more time, and has high risk [7]. This is a significant concern of the Information Technology (IT) Bureau as a provider of information technology services at BPK in developing a collaboration portal.

In addition to supporting administrative activities, the use of ICT in BPK also supports business processes for audit activities under the mandate of laws and regulations as a form of support for implementing e-government in Indonesia. The IT Bureau acts as an enabler in the use of IT. It encourages the implementation of integrated IT in all business processes to support BPK's vision of conducting quality audits and using information technology.

One of the efforts made by the IT Bureau is to summarize several problems from users, including:

- Complaints from employees regarding emails that are difficult to access and have limited storage capacity;

- Special attention from the BPK leader regarding free cloud-based storage media by both individual users and the audit team. In this case, it is concerned with data security and the confidentiality of documents stored on the cloud;

- An increasing need for virtual face-to-face and collaboration between teams and work units, including meetings, training, and socialization.

Based on these problems and the conformity with the implementation of BPK's strategic plan, since 2016, the IT Bureau has provided a collaboration portal platform service to answer these problems. These portal services include email services, eDrive (cloud-based employee data storage), and 
work unit information portals. The BPK cooperation portal plays an important role in obtaining information and providing effective and efficient services. The cooperation portal also plays a role in improving performance, productivity, and efficiency in implementing tasks between work units, both individually and in groups. However, the collaboration portal utilization assessment is based only on application usage statistics, such as counting the number of employees logged in to email and eDrive, which makes the organization unable to ensure that employees have utilized the collaboration portal service. In addition, the organization has not evaluated employees' perceptions of the use of collaboration portal services.

The primary objective of this study is to identify the factors affecting the collaboration portal effectiveness to improve job performance from the employee's perspective. BPK can obtain the effectiveness of the collaboration portal by analyzing the factors that influence the assessment of the quality of the portal, which can lead to an increase in satisfaction with the portal, thereby impacting individual job performance.

\section{LITERATURE REVIEW}

Many models have been proposed to assess the acceptance and information system success, including the technology acceptance model (TAM) [8]; DeLone and McLean information system success model (D\&M) [9], [10]; model of intention to use internet [11]; unified theory of acceptance and use of technology (UTAUT) [12], [13]; and others. However, it is not easy to determine the success of an information system because of the different stakeholders in assessing the system in which each group will evaluate according to their perspective [14]. There is no comprehensive theoretical framework for evaluating portal success since the use of the portal has been widely known. Based on this, D\&M model is considered capable of representing the assessment of portal effectiveness with quality assessment as a factor and has been tested by many empirical studies [15].

D\&M initial model was developed by identifying six factors in determining the success of an information system, including system and information quality, which influence the assessment of information system use and user satisfaction. While system use and user satisfaction influence each other, these variables also influence individual impact, which leads to organizational implications. Reference [9] then revised the previous model to respond to other researchers. Changes to this model include combining impact variables into net benefits, adding a new factor service quality as a contributor to information system success, and dividing the use variable into the intention to use and actual use.

Researchers have conducted several studies related to the success of information systems. Reference [16] conducted a study that combined and modified the D\&M model with UTAUT to determine the determinants the acceptance and system use level of open government data (OGD) in Bangladesh. This study showed that the variables significantly affecting behavioral intentions to use OGD were performance expectations, social influences, and effort expectancy, while facilitating conditions had no significant effect.

In determining the success factors of e-commerce in Malaysia, reference [17] used a modified D\&M model. Service quality, system quality, privacy, and trust were the four independent variables. According to the findings, the four independent variables had positive effects on user satisfaction. The modified D\&M and TAM models were used in a study [18]. The findings revealed that perceived usefulness was unaffected by collaboration quality or perceived ease of use.

On the other hand, the frequency of campus portal use is significantly influenced by perceived ease of use and perceived usefulness. Reference [19] conducted a study using a modified D\&M to analyze the factors affecting actual digital library use in Malaysia. According to the findings, service quality, system quality, and information quality significantly impacted on the behavioral intention and user satisfaction using a digital library. Reference [20] studied the factors affecting student satisfaction with university portals in developing countries. The results showed that service availability was the most influential factor on student satisfaction.

Based on these literature reviews, it is known that many previous studies were conducting using the D\&M, UTAUT, TAM, or even a combination of these models to analyze the success or effectiveness of an information system. However, the researcher believes that there are some differences if the analysis involves different variables. Therefore, the D\&M model was used to analyze the effectiveness of the BPK collaboration portal

\section{RESEARCH METHODOLOGY}

\section{A. Hypothesis and Research Model}

Organizations can evaluate the success and effectiveness of the portal from the frequency of use and user satisfaction with the quality and services [21]. This study proposed a model that assumes system quality, information quality, service quality, collaboration quality, and facilitation conditions have positive and significant effects on user satisfaction and individual job performance.

1) System Quality (SQ): The measurement of this variable focuses on information processing and information system characteristics. Many studies have been carried out by adding other assessment indicators in assessing the system's quality. Many users are benefiting from the increased use of the system. Therefore, the quality of the system is still a factor that determines the success of the information system. Indicators used to assess system quality include system flexibility, accessibility, system reliability, ease of learnings, response times, and functionality [16], [19], [20], [22], [23]. Several studies show that good system quality will increase user satisfaction in utilizing the system [17], [19], [20], [22]. This study proposed a hypothesis:

\section{H.1: System quality has a positive and significant influence on user satisfaction.}


2) Information Quality (IQ): The measurement of this variable focuses on the output of the information system. Indicators used to assess information quality variables include usefulness, understandability, completeness, relevance, accuracy, and timeliness [16], [19], [20], [22], [24], [25]. Several studies show that good information quality will increase user satisfaction in utilizing the system [17], [22]. This study proposed a hypothesis:

H.2: Information quality has a positive and significant influence on user satisfaction.

3) Service Quality ( $\mathrm{SeQ})$ : The measurement of this variable focuses on the quality of support received by system users from information service providers and IT support employees. Indicators used to assess service quality include responsiveness, assurance, reliability, and empathy of the IT personnel staff [22], [26]-[28]. Several studies show that better service quality will increase user satisfaction in utilizing the system [19], [20], [22]. This study proposes a hypothesis:

H.3: Service quality has a positive and significant influence on user satisfaction.

4) Collaboration Quality (CQ): One of the portal's characteristics is its ability to enable user collaboration [1]. The development of e-government makes ICT an important role in facilitating collaboration to change interaction and work culture in an organization. Collaboration requires coordination between two different entities that form a shared work area and information flow [3], facilitating integration, information exchange, and resource sharing [29]. In addition, the development of the portal also makes changes in collaboration. Therefore, the collaboration portal at BPK is expected to become a knowledge center and support collaboration between employees, improve and facilitate communication, and facilitate knowledge sharing between employees and work units.

ICT creates new habits where different teams can communicate and exchange information even though they are at different times and places. Each team must improve their knowledge and skills in getting work done, sharing, and collaborating with other teams. Increased productivity and innovation obtained by collaborating is carried out using the functions of knowledge sharing, social collaboration, and task sharing. Communication and collaboration that is carried out using formal or informal networks or through teamwork has an important role in the transformation, coordination, and application of information resources in terms of organizational decision-making, developing new ideas, and completing work. Therefore, collaboration requires a good level of knowledge sharing and an effective process to concern both individuals and organizations [30].

This study assumed that good collaboration quality would affect user satisfaction in using the system. Indicators used to assess collaboration quality include ease of use, effectiveness, the efficiency of various collaborative features, and productivity [1], [15], [22], [23]. This study proposed a hypothesis:

\section{H.4: Collaboration quality has a positive and significant influence on user satisfaction.}

5) Facilitating Conditions (FC): Facilitating conditions are defined as the infrastructure and services provided by the organization to support the use of information systems. Thus, it can be assumed that the better the facilitation conditions in supporting an information system, the higher the user satisfaction in utilizing the system. Indicators used to assess the facilitation condition variables include perceived behavioral control, facilitation conditions, and compatibility [31]-[33]. This study proposed a hypothesis:

\section{H.5: Facilitating Conditions have a positive and significant influence on user satisfaction.}

6) User Satisfaction (US): User satisfaction is a measure of user satisfaction in using an information system. This measure is used to assess the success of an information system. User satisfaction assessment is valid if the system used is mandatory. The satisfaction assessment includes evaluation of information quality, system quality, and service quality, not only measuring the level of user satisfaction [34]. This study assumed that high user satisfaction value would affect employee performance when working with the help of an information system. The indicators used to assess user satisfaction include adequacy, enjoyment, information satisfaction, system satisfaction, overall satisfaction [15], [20], [22], [23]. This study proposed a hypothesis:

\section{H.6: User satisfaction has a positive and significant influence} on individual job performance.

Many previous studies were conducted using D\&M, UTAUT, TAM, or even a combination of these models to analyze the success or effectiveness of an information system. However, there are some differences if the analysis applies different variables. Therefore, this study employed the D\&M model as the basis for assessing the effectiveness of the BPK collaboration portal. The "use/intention to use" variable in the D\&M model aims to assess the intention to use of information system. References [16], [18], [19] use the variable "use/intention to use" since the information system assessed is new and voluntary. In contrast, an organization cannot assess the "intention to use" variable in a mandatory system. Therefore, this paper modified the D\&M model by excluding "the use/intention to use" variable and focused on user satisfaction as the dependent variable.

This study proposed the individual job performance (IJP) variable replacing net benefit in the D\&M model as it focused on assessing the effectiveness of the collaboration portal in improving employee performance from the perspective of BPK employees. Meanwhile, in evaluating the effectiveness of an information system, reference [14] suggests that one of the things to assess is the impact. It is considered the most challenging part to determine as it is directly related to implementing an information system on individual and organizational performance. It is the same as the net benefit variable in the D\&M model, which aims to assess the system effectiveness whether it has direct benefits for organizations or individuals. 


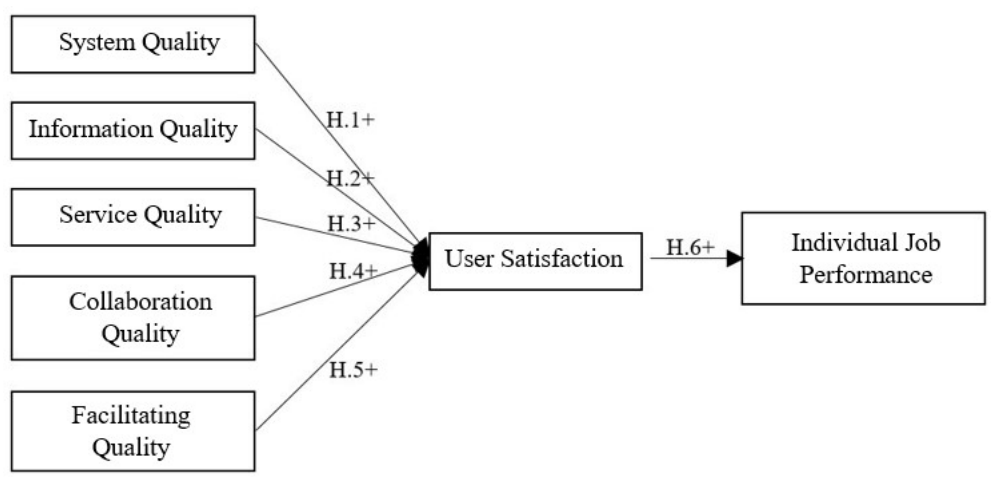

Fig. 1 Research model.

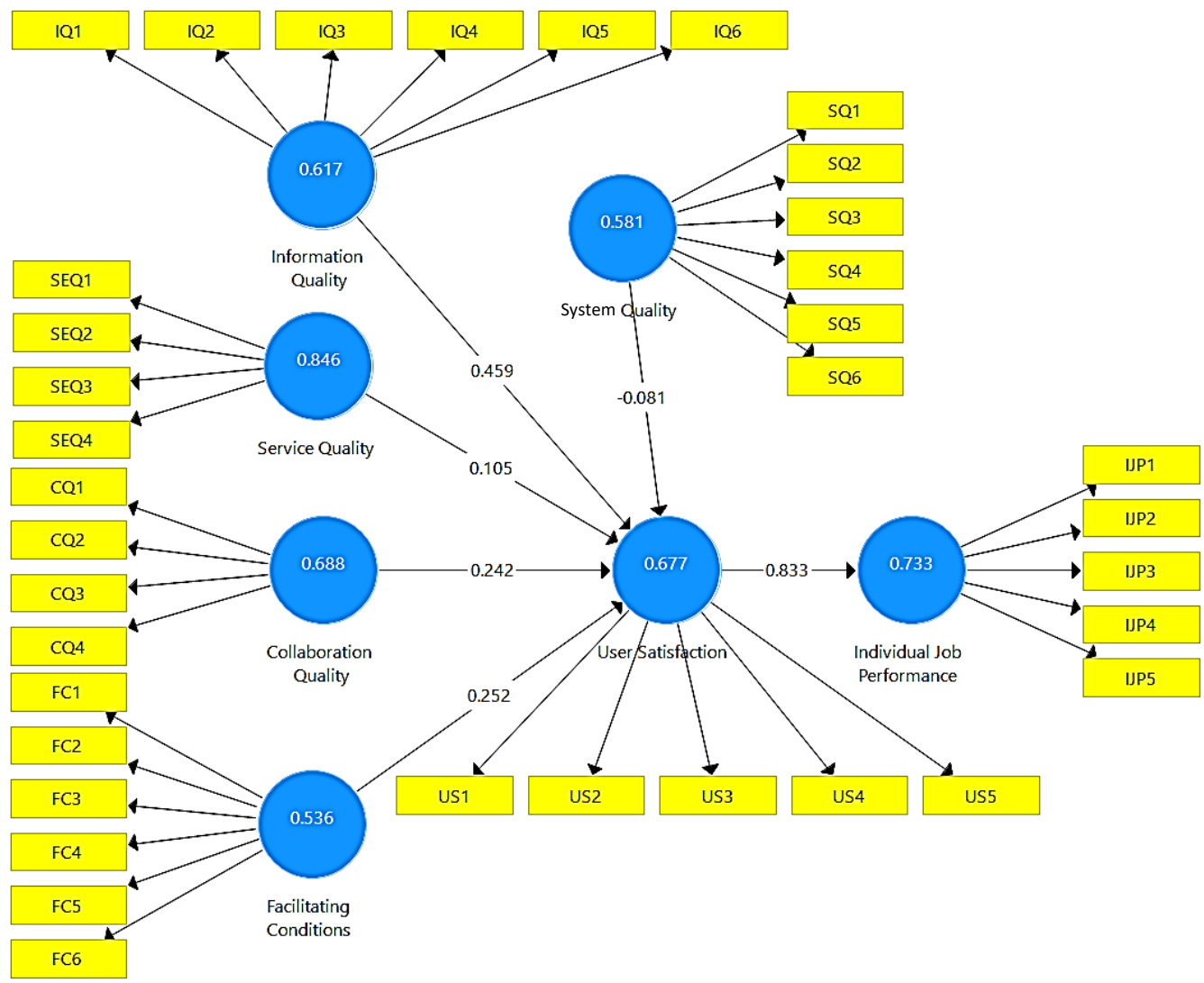

Fig. 2 Results of the loading factors outer model.

The theoretical model for assessing the effectiveness of the collaboration portal is shown in Fig. 1. Each arrow represents the hypothesis to be tested. The theoretical model was converted into an equation model and tested empirically.

\section{B. Methodology}

This study used a quantitative approach in the form of a survey with a questionnaire distributed to users of the collaboration portal. The assessment of indicators used a 4points Likert scale, ranging from 1 (strongly disagree) to 4 (strongly agree), with 60 respondents. The method used for data analysis was partial least squares-structural equation modeling (PLS-SEM), while the software used for data analysis was SmartPLS version 3.3.3.
SEM is a multivariate statistical analytic approach used to examine structural relationships between variables. PLS-SEM does not require data with the same distribution and can handle small sample sizes. Data analysis using PLS generally consists of two parts: the measurement model (outer model) and the structural (inner model) [35].

Outer model assessment explains the relationship between variables and their indicators. Convergent validity and discriminant validity assessments were carried out to check the validity of indicators and variables and assessed reliability as measured using composite reliability (CR) and Cronbach's alpha (CA). This assessment was carried out to validate whether the instrument used was valid and reliable. Convergence validity is a measure that shows the level of 
TABLE I

CONVERGENT VALIDITY

\begin{tabular}{|c|c|c|c|c|c|}
\hline Variable & Items & Loadings & CR & $\mathbf{C A}$ & AVE \\
\hline \multirow{6}{*}{ SQ } & SQ1 & 0.768 & \multirow{6}{*}{0.893} & \multirow{6}{*}{0.859} & \multirow{6}{*}{0.581} \\
\hline & SQ2 & 0.788 & & & \\
\hline & SQ3 & 0.808 & & & \\
\hline & SQ4 & 0.720 & & & \\
\hline & SQ5 & 0.751 & & & \\
\hline & SQ6 & 0.735 & & & \\
\hline \multirow{6}{*}{ IQ } & IQ1 & 0.754 & \multirow{6}{*}{0.906} & \multirow{6}{*}{0.877} & \multirow{6}{*}{0.617} \\
\hline & IQ2 & 0.725 & & & \\
\hline & IQ3 & 0.825 & & & \\
\hline & IQ4 & 0.786 & & & \\
\hline & IQ5 & 0.820 & & & \\
\hline & IQ6 & 0.799 & & & \\
\hline \multirow{4}{*}{$\mathrm{SeQ}$} & $\mathrm{SeQ1}$ & 0.931 & \multirow{4}{*}{0.957} & \multirow{4}{*}{0.940} & \multirow{4}{*}{0.846} \\
\hline & $\mathrm{SeQ} 2$ & 0.910 & & & \\
\hline & SeQ3 & 0.927 & & & \\
\hline & SeQ4 & 0.913 & & & \\
\hline \multirow{4}{*}{ CQ } & CQ1 & 0.816 & \multirow{4}{*}{0.898} & \multirow{4}{*}{0.851} & \multirow{4}{*}{0.688} \\
\hline & CQ2 & 0.796 & & & \\
\hline & CQ3 & 0.874 & & & \\
\hline & CQ4 & 0.829 & & & \\
\hline \multirow{6}{*}{$\mathrm{FC}$} & $\mathrm{FC} 1$ & 0.719 & \multirow{6}{*}{0.874} & \multirow{6}{*}{0.829} & \multirow{6}{*}{0.536} \\
\hline & $\mathrm{FC} 2$ & 0.706 & & & \\
\hline & FC3 & 0.709 & & & \\
\hline & $\mathrm{FC4}$ & 0.731 & & & \\
\hline & FC5 & 0.719 & & & \\
\hline & FC6 & 0.806 & & & \\
\hline \multirow{5}{*}{ US } & US1 & 0.862 & \multirow{5}{*}{0.913} & \multirow{5}{*}{0.880} & \multirow{5}{*}{0.677} \\
\hline & US2 & 0.795 & & & \\
\hline & US3 & 0.826 & & & \\
\hline & US4 & 0.794 & & & \\
\hline & US5 & 0.835 & & & \\
\hline \multirow{5}{*}{ IJP } & IJP1 & 0.841 & \multirow{5}{*}{0.932} & \multirow{5}{*}{0.908} & \multirow{5}{*}{0.733} \\
\hline & IJP2 & 0.916 & & & \\
\hline & IJP3 & 0.844 & & & \\
\hline & IJP4 & 0.876 & & & \\
\hline & IJP5 & 0.798 & & & \\
\hline
\end{tabular}

correlation between other indicators on the same variable. In this assessment, a set of indicators represented one variable and were considered to underlie that variable. The assessment was conducted to determine whether the questions on the instruments posed to the respondents to measure the research variables were valid. The value of convergent validity as measured by average variance extracted (AVE) for each variable must be greater than 0.5 , the loading value of each indicator must be greater than 0.7 , and the CR and CA on each variable must be greater than 0.7 .

Discriminant validity was tested at the level of indicators and variables. At the indicator level, discriminant validity was measured by the value of the loading indicator compared to the loading value of other variables (cross-loading). Validity will be fulfilled if the loading value of all indicators to the variable has the greatest value compared to the value of loading to other variables.
TABLE II

CORRELATION BETWEEN CONSTRUCTS AND THE SQUARE RoOT OF AVE

\begin{tabular}{|c|c|c|c|c|c|c|c|}
\hline & CQ & FC & IJP & IQ & SeQ & SQ & US \\
\hline CQ & 0.829 & & & & & & \\
\hline FC & 0.559 & 0.732 & & & & & \\
\hline IJP & 0.697 & 0.527 & 0.856 & & & & \\
\hline IQ & 0.600 & 0.532 & 0.633 & 0.786 & & & \\
\hline SeQ & 0.466 & 0.463 & 0.459 & 0.609 & 0.920 & & \\
\hline SQ & 0.426 & 0.466 & 0.349 & 0.623 & 0.430 & 0.762 & \\
\hline US & 0.673 & 0.642 & 0.833 & 0.752 & 0.579 & 0.470 & 0.823 \\
\hline
\end{tabular}

TABLE III

R-SQuARED TEST RESUltS

\begin{tabular}{|l|c|c|}
\hline \multicolumn{1}{|c|}{ Construct } & $\boldsymbol{R}^{\mathbf{2}}$ & Adjusted $\boldsymbol{R}^{\mathbf{2}}$ \\
\hline User satisfaction & 0.692 & 0.664 \\
\hline Individual job performance & 0.694 & 0.689 \\
\hline
\end{tabular}

The inner model describes the relationship between variables by looking at the proposed hypothesis's relationship/path coefficient $(\beta)$. The significance level of the relationship between variables can be seen from the t-statistic value. The inner model assessment also produces each dependent variable's coefficient of determination $\left(R^{2}\right)$. The $R^{2}$ value reflects the predictive power of the entire model. Path coefficient, t-statistic values, and $R^{2}$ were obtained using the bootstrapping method on the SmartPLS software [36].

\section{RESULTS}

\section{A. Outer Model Assessment}

The relationship between variables and indicators based on the research model can be seen in Fig. 2 The convergent validity analysis produced by the SmartPLS shows that the AVE value is greater than 0.5 , and the outer loading value of each indicator is greater than 0.7 . The $C R$ and $C A$ values also indicate that they are greater than 0.7 , which means convergent validity at the indicator and variable is good and in accordance with the provisions. Table I shows the results of the convergent validity testing.

Discriminant validity assessment shows that the loading value of each indicator has followed the provisions. At the variable level, discriminant validity was measured by comparing the AVE root value of a variable with the correlation between a variable and another variable. If the AVE root value is greater than the correlation of other variables, discriminant validity follows the provisions as shown in Table II. The results of the outer model assessment show that all the criteria have followed the provisions, so all indicators and variables used in this study are valid and reliable.

\section{B. Inner Model Assessment}

Table III shows that the user satisfaction variable has an $R^{2}$ value of 0.692 , which means that this variable can be explained by $69 \%$ of the variables in this study. The individual job performance variable has an $R^{2}$ value of 0.694 , which means that this variable can be explained by $69 \%$ of variables in this study. At the same time, the rest is explained by other variables 
TABLE IV

PATH COEFFICIENT AND HyPOTHESIS TeSTING

\begin{tabular}{|c|l|c|c|c|}
\hline Hypothesis & Relations & $\boldsymbol{\beta}$ & t-statistic & Result \\
\hline H.1 & SQ $\rightarrow$ US & -0.081 & 0.691 & Not Significant \\
\hline H.2 & IS $\rightarrow$ US & 0.459 & 3.342 & Significant \\
\hline H.3 & SeQ $\rightarrow$ US & 0.105 & 0.853 & Not Significant \\
\hline H.4 & CQ $\rightarrow$ US & 0.242 & 2.215 & Significant \\
\hline H.5 & FC $\rightarrow$ US & 0.252 & 2.400 & Significant \\
\hline H.6 & US $\rightarrow$ IJP & 0.833 & 16.612 & Significant \\
\hline
\end{tabular}

not included in this study. Path coefficient and t-statistic values can be seen in Table IV.

\section{Interpretation of Hypothesis Testing Results}

Interpretation of hypothesis used to determine whether the hypothesis is accepted or rejected. The t-statistic value was compared with the t-table value. The hypothesis is accepted if the $t$-statistic value from this test is greater than the t-table. The significance test was carried out with a one-tailed test, and the value of significance level $(\alpha)$ is 0.05 or $5 \%$, then the t-table value used was 1.671. Table IV shows the outcomes of hypothesis testing.

Good characteristics and qualified system performance will significantly affect and increase user satisfaction in using the system [37]. Table IV shows that the value of t-statistic system quality is 0.691 , which is smaller than the value of the t-table. In contrast, the path coefficient has a negative value of -0.081 . These results suggest the perception that system quality has a significant and positive influence on user satisfaction (H.1) is rejected. The path coefficient value $(\beta)$ shows a negative value means that system quality does not influence user satisfaction in using the collaboration portal, different from previous research [19], [20], [38], [39], which state that better system quality will increase user satisfaction. This difference may be due to BPK employees' familiarity with the performance and characteristics of the collaboration portal as the use of the collaboration portal is mandatory.

H.2 indicates that better system quality will increase user satisfaction in utilizing the system [37]. Table IV shows the tstatistic information quality value is 3.342 , greater than the $t$ table value, while the path coefficient has a positive value of 0.459 . The results indicate that the information quality has a significant and positive influence on user satisfaction (H.2) is accepted. The positive path coefficient value indicates that the greater information quality, the greater the perceived user satisfaction. This result is supported by previous research [19], [20], [39].

H.3 is based on the model of D\&M. Better service quality will increase user satisfaction in utilizing the system [37]. Table IV shows that the value of t-statistic service quality is 0.853 , smaller than the value of the t-table. In contrast, the path coefficient is 0.105 . The results indicate that the perception of system quality has a significant and positive and influence on user satisfaction (H.3) is rejected. The result suggest that the perception of better system quality provided by the supporting work unit of the collaboration portal service provider has no significant influence on user satisfaction in using the collaboration portal. It is in line with previous research [38], [39], [40], but it is different from other studies [19], [41]. The difference can occur because the characteristics of the collaboration portal are quite good, and users rarely interact with supporting work units. However, it does not increase user satisfaction in utilizing the collaboration portal.

Table IV shows that the value of t-statistic collaboration quality is 2.215 , greater than the value of the t-table. In contrast, the path coefficient is 0.252 . This result indicates that the perception of collaboration quality significantly influences user satisfaction (H.4) is accepted. The positive path coefficient value of 0.252 indicates that the greater the perception of collaboration quality, the greater the perceived user satisfaction. Previous research confirms this finding [15], [42], which means that the higher the perception of collaboration quality, the perception of user satisfaction on using the collaboration portal will also increase. On the contrary, if the collaboration quality is perceived as less good by the users, user satisfaction on the collaboration portal will also be lower.

Facilitating conditions t-statistic value shown in Table IV is 2.400 , which is greater than the value of the t-table. In contrast, the path coefficient is 0.252 . These results indicates that the perception of facilitating conditions has a significant and positive influence on user satisfaction (H.5) is accepted. The positive path coefficient value indicates that better facilitating conditions provided by the supporting work unit for collaboration portal service providers significantly influence the perception of user satisfaction in using the collaboration portal. On the contrary, if the users perceive the supportive facilities as less good, user satisfaction on the collaboration portal will also be lower.

The last hypothesis t-statistic value shown in Table IV displays that the t-statistic value of user satisfaction is 16.612 , which is greater than the t-table value. In contrast, the path coefficient is 0.833 . These results indicate that the perception of user satisfaction has a significant and positive influence on individual job performance (H.6) is accepted. The positive path coefficient value indicates that higher user satisfaction for collaboration portal services significantly influences individual perceptions of employee job performance. Meanwhile, if users perceive user satisfaction value as less good, the individual perceptions of job performance will also be lower.

\section{CONCLUSION}

Based on the results of testing and data analysis, it can be concluded that several factors can be used to assess the effectiveness of the collaboration portal, including information 
quality, collaborations quality, facilitating conditions, and user satisfaction. Information quality, collaboration quality, and facilitating conditions increase user satisfaction using collaboration portal services and improve individual job performance. Meanwhile, the collaboration portal system quality and service quality turn out to be ineffective and are considered unable to provide employee user satisfaction in using collaboration portal services. Therefore, the IT Bureau must evaluate the quality improvement on these factors. In addition, the factor that is considered the most effective is the user satisfaction of the collaboration portal service, which is expected to increase the individual job performance of the employees as indicated by the most significant path coefficient value.

\section{REFERENCES}

[1] H. Benbya, G. Passiante, and N.A. Belbaly, "Corporate Portal: A Tool for Knowledge Management Synchronization," International Journal of Information Management, Vol. 24, No. 3, pp. 201-220, Jun. 2004.

[2] C. Dias, "Corporate Portals: A Literature Review of a New Concept in Information Management," International Journal of Information Management, Vol. 21, No. 4, pp. 269-287, Aug. 2001.

[3] C.S. Pereira and A.L. Soares, "Improving the Quality of Collaboration Requirements for Information Management Through Social Networks Analysis," International Journal of Information Management, Vol. 27, No. 2, pp. 86-103, Apr. 2007.

[4] F. Sulaiman, S. Zailani, and T. Ramayah, "Intranet Portal Utilization: Monitoring Tool for Productivity - Quality and Acceptance Point of View," Procedia Social and Behavioral Sciences, Vol. 65, 2021, pp. 381386.

[5] M. Brown, C. Mines, C. Moore, and J. Barnett, "Companies Adopt Employee Portals, Not Portal Best Practices," Forrester Research Inc., Cambridge, USA, Jan. 2007.

[6] N. Urbach and T. Würz, "Designing a Reference Framework of IT/IS Outsourcing Steering Processes," 19th European Conference on Information Systems, ECIS 2011, 2011, pp. 1-13.

[7] U. Remus, "Critical Success Factors for Implementing Enterprise Portals a Comparison with ERP Implementations," Business Process Management Journal, Vol. 13, No. 4, pp. 538-552, Jul. 2007.

[8] F.D. Davis and F. Davis, "Perceived Usefulness, Perceived Ease of Use, and User Acceptance of Information Technology," MIS Quarterly, Vol. 13, No. 3, pp. 319-340, Sep.1989.

[9] W.H. DeLone and E.R. McLean, "Information Systems Success: The Quest for the Dependent Variable," Information Systems Research, Vol. 3, No. 1, pp. 60-95, Mar. 1992.

[10] W.H. DeLone and E.R. McLean, "The DeLone and McLean Model of Information Systems Success: A Ten-Year Update," Journal of Management Information Systems, Vol. 19, No. 4, pp. 9-30, Apr. 2003.

[11] M.K. Chang and W. Cheung, "Determinants of the Intention to Use Internet/WWW at Work: A Confirmatory Study," Information \& Management, Vol. 39, No. 1, pp. 1-14, Nov. 2001.

[12] V. Venkatesh, M.G. Morris, G.B. Davis, and F.D. Davis, "User Acceptance of Information Technology: Toward a Unified View," MIS Quarterly, Vol. 27, No. 3, pp. 425-478, Sep. 2003.

[13] V. Venkatesh, J.Y.L. Thong, and X. Xu, "Consumer Acceptance and Use of Information Technology: Extending the Unified Theory of Acceptance and Use of Technology," MIS Quarterly, Vol. 36, No. 1, pp. 157-178, Mar. 2012

[14] V. Grover, S.R. Jeong, and A.H. Segars, "Information Systems Effectiveness: The Construct Space and Patterns of Application," Information \& Management, Vol. 31, No. 4, pp. 177-191, Dec. 1996.

[15] N. Urbach, S. Smolnik, and G. Riempp, “An Empirical Investigation of Employee Portal Success," The Journal of Strategic Information Systems, Vol. 19, No. 3, pp. 184-206, Sept. 2010.
[16] S. Talukder, L. Shen, F.H Talukder, and Y. Bao, "Determinants of User Acceptance and Use of Open Government Data ( OGD ): An Empirical Investigation in Bangladesh," Technology in Society, Vol. 56, pp. 147 156, Feb. 2019.

[17] N.I. Ali, S. Samsuri, I.A. Brohi, A.B. Soomro, S. Soomro, and A. Shah, "Preliminary Study on Factors Affecting E-Commerce Success: A Modified Delone and Mclean Model," 2018 International Conference on Information and Communication Technology for the Muslim World, 2018, pp. 120-125.

[18] M. Saghapour, M. Iranmanesh, S. Zailani, and G.G.G. Goh, "An Empirical Investigation of Campus Portal Usage," Education and Information Technologies, Vol. 23, No. 2, pp. 777-795, 2018.

[19] A.I. Alzahrani, I. Mahmud, T. Ramayah, O. Alfarraj, and N. Alalwan, "Modelling Digital Library Success Using the Delone and Mclean Information System Success Model," Journal of Librarianship and Information Science, Vol. 51, No. 2, pp. 1-16, Aug. 2017.

[20] A.M. Shaltoni, H. Khraim, A. Abuhamad, and M. Amer, "Exploring Students Satisfaction with Universities Portals in Developing Countries," International Journal of Information and Learning Technology, Vol. 32, No. 2, pp. 82-93, Mar. 2015.

[21] D. Jalal and M.M. Al-Debei, "Portals and Task Innovation: A Theoretical Framework Founded on Business Intelligence Thinking," Aug. 2012.

[22] G. Chopra, P. Madan, P. Jaisingh, and P. Bhaskar, "Effectiveness of ELearning Portal from Students Perspective: A Structural Equation Model (SEM) Approach," Interactive Technology and Smart Education, Vol. 16, No. 2, pp. 94-116, Mar. 2019.

[23] G.G. Gable, D. Sedera, and T. Chan, "Re-Conceptualizing Information System Success: The IS-Impact Measurement Model," Journal of the Association for Information Systems, Vol. 9, No. 7, pp. 377-408, Oct. 2008.

[24] D. Sedera and G.G. Gable, "A Factor and Structural Equation Analysis of the Enterprise Systems Success Measurement Model," Proceedings of the Tenth Americas Conference on Information Systems, 2004, pp. 676-482.

[25] J. Iivari, "An Empirical Test of the Delone-Mclean Model of Information System Succes," ACM SIGMIS Database: the DATABASE for Advances in Information Systems, Vol. 36, No. 2, pp. 8-27, Jun. 2005.

[26] T. Ahn, S. Ryu, and I. Han, "The Impact of the Online and Offline Features on the User Acceptance of Internet Shopping Malls," Electronic Commerce Research and Applications, Vol. 3, No. 4, pp. 405-420, 2004.

[27] L.F. Pitt, R.T. Watson, and C.B. Kavan, "Service Quality: A Measure of Information Systems Effectiveness," MIS Quarterly, Vol. 19, No. 2, pp. 173-187, Jun. 1995.

[28] J.C.J. Chang and W.R. King, "Measuring the Performance of Information Systems: A Functional Scorecard," Journal of Management Information Systems, Vol. 22, No. 1, pp. 85-115, Jun. 2005.

[29] M.E. Johnson and S. Whang, "E-Business and Supply Chain Management: An Overview and Framework," Nov. 2002.

[30] A. Anders, "Team Communication Platforms and Emergent Social Collaboration Practices," International Journal of Business Communication, Vol. 53, No. 2, pp. 224-261, Apr. 2016.

[31] I. Ajzen, "The Theory of Planned Behavior," Organizational Behavior and Human Decision Processes, Vol. 50, No. 2, pp. 179-211, Dec. 1991.

[32] S. Taylor and P.A. Todd, "Understanding Information Technology Usage," Information Systems Research, Vol. 6, No. 2. pp. 144-176, Jun. 1995.

[33] R.L. Thompson, C.A. Higgins, and J.M. Howell, "Personal Computing: Toward a Conceptual Model of Utilization," MIS Quarterly, Vol. 15, No. 1, pp. 125-143, Mar. 1991.

[34] N. Urbach and B. Müller, "The Updated DeLone and McLean Model of Information Systems Success," in Information Systems Theory: Explaining and Predicting Our Digital Society, Vol. 1, Y.K. Dwivedi, M. Wade, and S. L. Schneberger, Eds. New York, USA: Springer, 2011, pp. $1-18$.

[35] P.I. Santosa, Metode Penelitian Kuantitatif - Pengembangan Hipotesis dan Pengujiannya Menggunakan SmartPLS. Sleman, D.I. Yogyakarta: Andi, 2018. 
[36] J.F. Hair, C.M. Ringle, and M. Sarstedt, "PLS-SEM: Indeed a Silver Bullet," Journal of Marketing Theory and Practice, Vol. 19, No. 2, pp. 139-152, 2011.

[37] W.H. DeLone and E.R. McLean, Information Systems Success Measurement. Massachusetts, USA: Now Publishers Inc., 2016.

[38] A.J.H. Hambali, "The Success of E-Filing Adoption during COVID 19 Pandemic: The Role of Collaborative Quality, User Intention, and User Satisfaction," Journal of Economics, Business, \& Accountancy Ventura, Vol. 23, No. 1, pp. 57-68, Apr.-Jul. 2020.

[39] W.A. Cidral, T. Oliveira, M. Di Felice, and M. Aparicio, "E-Learning Success Determinants: Brazilian Empirical Study," Computers \& Education, Vol. 122, pp. 273-290, Jul. 2018.
[40] M.M. Al-Debei, D. Jalal, and E. Al-Lozi, "Measuring Web Portals Success: A Respecification and Validation of the Delone and Mclean Information Systems Success Model," International Journal of Business Information Systems, Vol. 14, No. 1, pp. 96-133, Aug. 2013.

[41] S.I. Dasuki and M.N. Yakubu, "Assessing Elearning Systems Success in Nigeria: An Application of the Delone and Mclean Information Systems Success Model," Journal of Information Technology Education: Research, Vol. 17, pp. 182-202, 2018.

[42] J.V. Chen, Y. Chen, and E.P.S. Capistrano, "Process Quality and Collaboration Quality on B2B E-Commerce," Industrial Management \& Data Systems, Vol. 113, No. 6, pp. 908-926, Jun. 2013. 